\title{
Air treatment research of volatile organic compounds by drip-biofilter with cross-polymer charge
}

\author{
Giedre Jakstaite ${ }^{\mathrm{a}}$, Alvydas Zagorskis ${ }^{\mathrm{b}}$ \\ ${ }^{a}$ Svajoniu st. 5, 14168 Vilnius, Lithuania \\ ${ }^{b}$ Sauletekio ave. 11, 10223 Vilnius, Lithuania
}

\begin{abstract}
This experimental scientific work aims to determine the performance of the bio filter, when treated by a complex polymeric charge. To clean the air of the vocs, a new filter comprising of a complex woven polymer material using a lining of lavsano was used. State of St. Petersburg University of Technology and Design collaborated in selecting the complex polymeric charge. The charge has the following parameters: charge density of 1.38 to $1.39 \mathrm{~g} / \mathrm{cm}^{3}$, the number of threads is $31-192$, deformation under tension $12-16 \mathrm{kPa}$, porosity 0.99 and the surface area of $-104 \mathrm{~m}^{2} / \mathrm{m}^{3}$. The research carried out using the biofilter was created by the Department of Environmental Protection in Vilnius Gediminas Technical University. The aim is to establish the efficiency of the biofilter to clean the air of acetone, butanol and xylene vapors at varying boot layer heights, pollutant concentrations and gas flows while burdened by complex polymeric charges. For the test we used a volatile organic compounds concentration detection device - photoionization detector MiniRAE - 2000 from American firm RaeSystems. The Test revealed the air cleaning efficiency of the biofilter at different air flows and pollutants (wetcharge) from the gas emishion. Research were carried out using three volatile organic compounds: acetone, butanol. Based on test results, the maximum air biofilter treatment efficiency reached $85 \%$. The most efficient treatment of the contaminated xylene vapors achieved through the device was at $2.41 \mathrm{~m}^{3} / \mathrm{hr}$ productivity.
\end{abstract}

Keywords: Acetone, biofilter, butanol, efficiency, charge.

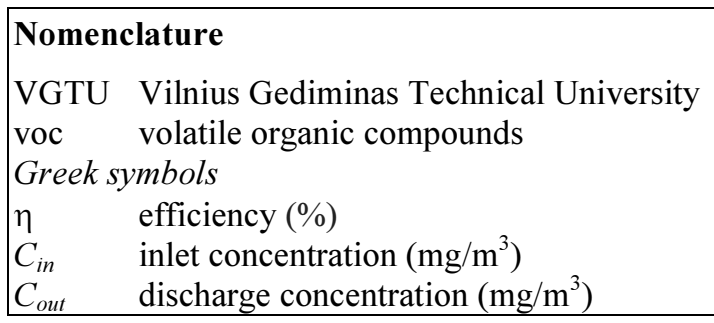

\section{Introduction}

One of the most significant aspects of the environmental damage in XXI century is strongly increased air pollution that has spread beyond national boundaries (Andres et al., 2009). Air pollution is associated with one of the most important contemporary environmental threats - climate change. This phenomenon is seen as a complex process, with a global negative impact. Global impact of climate change confirms the fact that currently the majority of the environmental threats are international, because destructive environmental actions in one country or region can have negative consequences for other countries or regions. For this reason, efforts to combat ecological threats can no longer be confined to the national level. Therefore, together with the other European Union Member States, Lithuania has committed to reduce emissions of volatile organic compounds (VOC) emissions to the environment by signing in 1999 "Long-range Transboundary Air Pollution" protocol to the convention "On the emission of volatile organic compounds and their transboundary fluxes limitation" which has been adopted in 1979.

Mostly the atmosphere is polluted with these gases: sulfur, nitrogen and carbon oxides, ammonia, freons gas, as well as materials that can be in aerosolized and vapor state, such as VOCs and others. According to Lithuanian Department of

Corresponding author: Giedre Jakstaite. E-mail address: giedre.jakstaite@gmail.com

http://dx.doi.org/10.3846/enviro.2014.027

(C) 2014 The Authors. Published by VGTU Press. This is an open-access article distributed under the terms of the Creative Commons Attribution License, which permits unrestricted use, distribution, and reproduction in any medium, provided the original author and source are credited. 
Statistics, during 2010, mainly stationary sources emitted carbon monoxide, sulfur dioxide and volatile organic compounds (VOCs). During the year 2010 there were 16642.60 tons of volatile organic compounds emitted. As per emissions by stationary sources these pollutants are in third place after the carbon monoxide and sulfur dioxide.

Volatile organic compounds - liquids or solids which contain organic carbon. They are one of the largest groups of organic materials, which affects our environment (Koltuniewicz and Drioli, 2008). The VOC not only deteriorates urban air quality, tropospheric ozone is also formed. In the light of the sun, some VOCs react with nitrogen oxides in the atmosphere and forms smog, when VOCs penetrates to higher layers of the atmosphere it begins to destroy the ozone layer and thus reduces the protective layer of the Earth, which can be disastrous both for us and for future generations (Saravanan and Rajamohan, 2009; Comilla et al., 2004).

\subsection{Biological air cleaning method}

Although today's world is closely bound with political and economic interests, but in order to avoid irreversible and potentially catastrophic climate changes in the system and to ensure the quality of life, it is necessary to search as well as apply more efficient, cheaper methods of biological waste air cleaning that do not leave waste, which ensures the efficient operation of certain cultures (Deshusses, 1997; Miao et al., 2005; Eldon et al., 2010).

Biological air cleaning method (biofiltration) is based on the removal of volatile organic compounds from polluted air and the removal of certain cultures of micro-organisms living in the bio-load and the ability to break down, oxidize or assimilate pollutants detained. During biological air cleaning process due to billions of microorganisms both organic and inorganic contaminants are broken down to harmless products of decomposition: first, to intermediate, with less energy fission products, and the latter to the end of their degradation products - carbon dioxide, water and other odorless gas. This process is known as biodegradation. Of course, these microorganisms consume only safely activated compounds in a humid, oxygen-rich environment (Emmanuel et al., 2004; Pineda et al., 2004; Zarook et al., 1997).

Biological air cleaning method is not only effective, removing odors and being environmentally friendly, but is also cheaper than thermal, mechanical or chemical. Also, this air purifying method is successfully applied to wastewater treatment facilities, glue, oil, chemical and tobacco industries ( McNevin and Barford , 2000; Duan et al., 2006).

\subsection{Technologies applied in volatile organic compounds cleaning}

Most frequently air is cleaned from common pollutants using traditional air cleaning methods, but they are usually not justified due to high energy costs, the large quantities of waste, an expensive investment, for example expensive catalysts are used to clean air through catalytic oxidation and this method is only suitable for low - polluted air cleaning. Hence, the biological air cleaning methods with high removal efficiency are used. During biological air cleaning different design, different working principle, various bio - load filled facilities are used.

Usually there are two types of biofilter systems: traditional biofilters filled with natural organic matter and biofilters with loads of synthetic origin (Cai et al., 2006). Analysing biofilters constructions and used loads used for biofiltration some major drawbacks appear, such as high aerodynamic load drag, resulting in higher costs for energy; currently used synthetic loads are expensive which increases the cost of installation and operation costs (Nicolai and Janni, 2001).

Therefore one of the most important parameters of the biofilter efficiency is the filtering substance (Ardjmand et al., 2005). The load used in the installations can be classified into fixed or mobile. The choice is determined by the chemical nature of the contaminants quantity of conatminants, etc. (Neves et al., 2006).

In order to increase the surface area of the load and the time of usage drip biofilters are loaded with synthetic inorganic charge, which is watered with activated nutrients saturated solution. Also the biological air cleaning methods are used to clean air from even higher concentrations of pollutants (more than $2000 \mathrm{mg} / \mathrm{m}^{3}$ ) (Baltrènas and Zagorskis, 2010).

\section{Analysis of research and discussion of results}

\subsection{Biofilter characteristics}

Research was carried out using drip-biofilter, loaded with with artificial load, developed in Vilnius Gediminas Technical University (Faculty), Department of Environmental Protection (Fig. 1). 


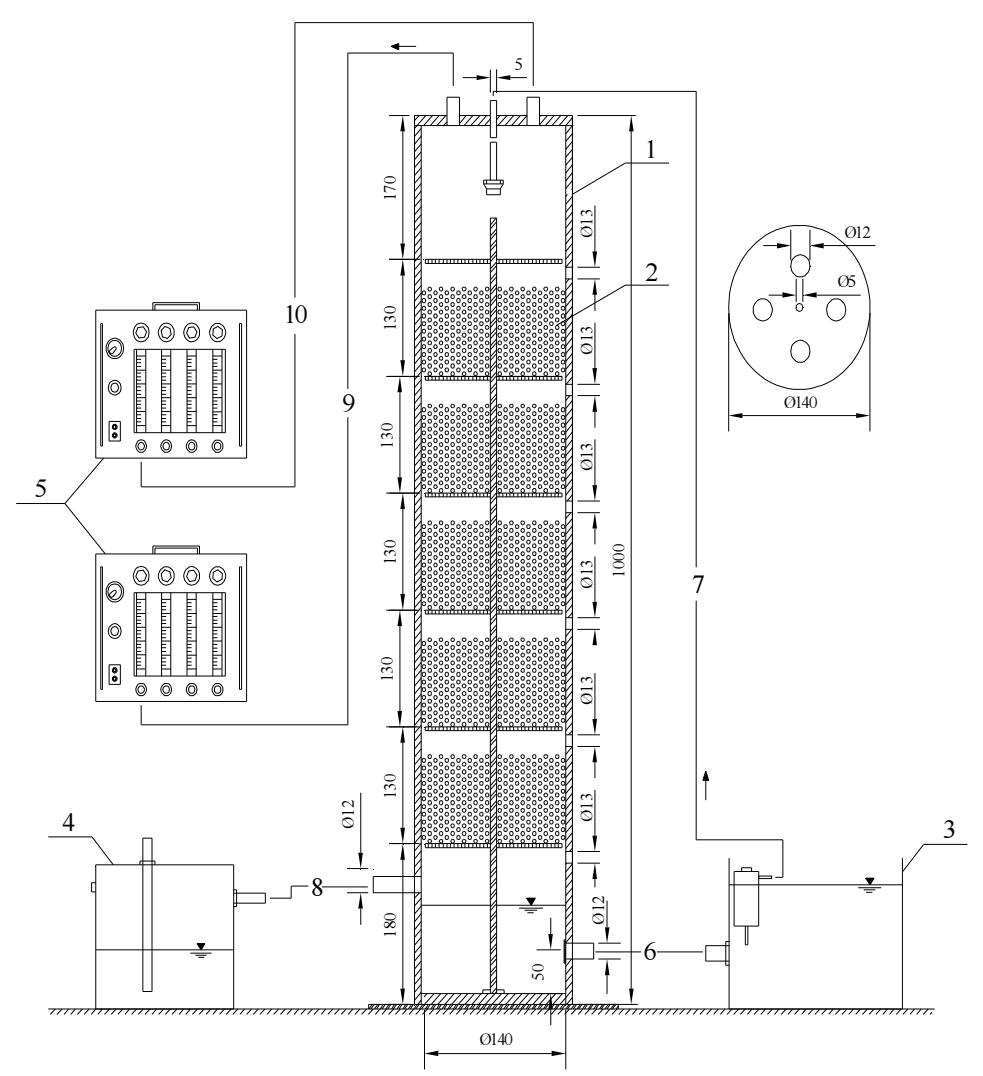

Fig. 1. Drip - biofilter scheme: 1 - biofilter body; 2 - load; 3 - circulating water tank; 4 - contaminants supply chamber; 5 - aspirator;

$6,7,8,9,10$ - rubber connecting hoses (Zagorskis and Spiečiūtè 2011)

Biofilter consists of a housing 1 , height $-1.0 \mathrm{~m}$, diameter $-14.0 \mathrm{~cm}$, load is charged inside 2, circulating water tank is also connected 3, pollutants supply chamber 4 , system of aspirators 5 , which regulates pulled air flow. There are five sections installed in biofilter, through which polluted air is allowed. After each section there are $0.013 \mathrm{~m}$ diameter openings sealed with retractable rubber stoppers installed, for measuring of needed physical parameters, pollutant concentrations, speed and other tests required. Circulating water tank is filled with water and microorganisms "Pseudomonas".

\subsection{Bio-load characteristics}

As already mentioned, one of the most important parameters of the biofilter efficiency is filtering substance or just load. The choice is determined by the chemical nature of the contaminants, quantity of emitted pollutants, etc. Using biofilter to clean the air from VOCs new load is used consisting of complex woven polymeric materials with lavsano insert (Table 1). Loading is chosen in collaboration with the St. Petersburg University of Technology and Design.

Table 1. The load is characterized by the following parameters

\begin{tabular}{lll}
\hline Parameters & $\begin{array}{l}\text { Parameters of measurement } \\
\text { units }\end{array}$ & Value \\
\hline Density & $\mathrm{g} / \mathrm{cm}^{3}$ & $1.38-1.39$ \\
Fiber number of units & vnt. & $31-192$ \\
Deformation at the tensile & $\mathrm{kPa}$ & $12-16$ \\
Porosity & units parts & 0.99 \\
Surface are & $\mathrm{m}^{2} / \mathrm{m}^{3}$ & 104 \\
\hline
\end{tabular}




\subsection{Course of the experiment}

Research has been carried out with these volatile organic compounds: acetone, butanol. First we prepare the appropriate VOC solution. Dilute the pollutant with a certain amount of distilled water, the initial concentration of pollutants are following: $350 \pm 2 \mathrm{ppm}, 270 \pm 2 \mathrm{ppm}$ and $180 \pm 2 \mathrm{ppm}$. Studies are carried out in a neutral medium $(\mathrm{pH}=7.0)$.

Biofilter load airflow volume is regulated by the help of two aspirators 5 . After each section there are $0.013 \mathrm{~m}$ diameter openings sealed with retractable rubber (glass) plugs installed, for measuring of needed physical parameters, pollutant concentrations, speed and other tests required. Measurements were carried out at different air flows: $0.001330 \mathrm{~m}^{3} / \mathrm{s}$ $(80 \mathrm{l} / \mathrm{min}), 0.00100 \mathrm{~m}^{3} / \mathrm{s}(60 \mathrm{l} / \mathrm{min})$ and $0.000667 \mathrm{~m}^{3} / \mathrm{s}(40 \mathrm{l} / \mathrm{min})$. In order to evaluate the effectiveness of the load, the pollutant concentrations are measured after each section at three different air volumes. Each measurement is repeated 3 times in 5 places (after each section there are openings installed for measurement of pollutant concentrations, speed and other characteristics relevant to the research).

Circulating water tank 3 is filled with water and microorganisms, then with the help of circulation pump it is pumped to drip - filter upper part, where is sprayed with the nozzle and distributed evenly in diameter of the filter housing 1 . Activated sprayed droplets of water is in contact with the load 2 and penetrates the sections below through metal sieves openings. Microorganisms in the water are adsorpting on the surface of the load, forming the biofilm. After even biofilm is formed in all five sections, the pollutant water supply chamber is filled with the appropriate amount of a pollutant solution to achieve the desired contaminant vapor concentration, air pulling speed is adjusted by aspirators. Then the pollutant emissions from pollutant supply chamber are drawn vertically up through the five sections of the biofilter. Pulled contaminant vapor concentrations are measured after each section, efficiency of the filter treatment changes are monitored.

Pollutant concentrations are measured using the American firm RaeSystems volatile organic compounds concentration detection device MiniRAE - 2000. This device uses a new generation of UV discharge lamp without electrode. When organic compounds are transported near the lamp, they are foto-ionized and free electrons are captured as an electric current. PID sensor with standard $10.6 \mathrm{eV}$ lamp can record a wide range of organic vapors. MiniRAE - 2000 measurements range from $0 \mathrm{iki} 7000 \mathrm{mg} / \mathrm{m}^{3}$. The measurement accuracy of the pollutant concentration at $0-2000 \mathrm{ppm}$ is $\pm 2 \mathrm{ppm}$ or $10 \%$ of reading. Pollutant concentrations at $>2000 \mathrm{ppm}$, accuracy is $\pm 20 \%$ of reading. Pollutants pulling speed of the device $450-550 \mathrm{~cm}^{3} / \mathrm{min}$.

Portable MiniRAE - 2000 is a compact of volatile organic compounds (VOC) control device, designed as a broadband VOC emission control device and information registrar, designed to work in hazardous environments. It provides real-time measurements and activates alarm signals whenever the yield is in excess of the prescribed limits. Before transporting the device from the factory danger limits are pre-set, the sensor is calibrated using the standard gas. However, the user should check the appliance before first use and perform the calibration. When the control device is fully loaded and calibrated, it is ready for operation.

\subsection{Experimental data processing formula}

First it is necessary to calculate pollutant concentrations (ppm) to $\mathrm{mg} / \mathrm{m}^{3}$, it is done as follows:

$$
C_{2}=\left(C_{1} \cdot M\right) / 24.04
$$

here: $C_{2}$ - chemical mass concentration, $\mathrm{mg} / \mathrm{m}^{3} ; C_{l}$ - chemical mass concentration, $\mathrm{ppm} ; M$ - molecular weight of the substance, $\mathrm{g} / \mathrm{mol} ; 24.04-$ molar volume, $1 / \mathrm{mol}$. It applies when the temperature is $20{ }^{\circ} \mathrm{C}$ and atmospheric pressure is $101.3 \mathrm{kPa}(760 \mathrm{mmHg})$.

Using volatile organic compound concentrations device MiniRAE - 2000, biofilter efficiency can be calculated:

$$
\eta=\left(C_{\text {in }}-C_{\text {out }}\right) / C_{\text {out }} \cdot 100 \text {; }
$$

here: $\eta$ - efficiency, \%; $C_{i n}$ - the initial chemical mass concentration, $\mathrm{mg} / \mathrm{m}^{3} ; C_{\text {out }}$ - concentration of the substance in a certain section of the device, $\mathrm{mg} / \mathrm{m}^{3}$.

Concentration is measured 3-5 minutes. After measuring device provides the averaged medium and maximum value in order to find the most values as exact as possible.

\subsection{Air purification from volatile organic compounds efficiency results}

Atlik Experimental studies have demonstrated the air biofilter treatment efficiency dependence on the supply of different contaminant vapor concentration. Measurements were carried out at two different initial concentrations of pollutants: acetone: a) $830.27 \mathrm{mg} / \mathrm{m}^{3}$; b) $640.49 \mathrm{mg} / \mathrm{m}^{3}$; c) $426.99 \mathrm{mg} / \mathrm{m}^{3}$; butanol: a) $1061.05 \mathrm{mg} / \mathrm{m}^{3}$; b) $818.52 \mathrm{mg} / \mathrm{m}^{3}$; c) $545.12 \mathrm{mg} / \mathrm{m}^{3}$.

Air biocleaning research from acetone. At the initial concentration of acetone $830.27 \mathrm{mg} / \mathrm{m}^{3} \mathrm{I}$ have found that the efficiency of the biofilter, at different air flows, varies from $45 \%$ to $79 \%$ (Fig. 2.). When air flow is $0.00133 \mathrm{~m}^{3} / \mathrm{s} \mathrm{s}$ biofilter performance after the first charge layer was $45 \%$, after the second layer $-51 \%$, after the third layer $-58 \%$, after the fourth $63 \%$, while the fifth has risen to $65 \%$. When air flow has been reduced to $0.00100 \mathrm{~m}^{3} / \mathrm{s}$ I have noticed that the efficiency of the first layer of the load was $51 \%$, after the second layer $-55 \%$, after the third layer $-61 \%$, after the fourth $-64 \%$, while 
the fifth has risen to $71 \%$. Measurements were repeated with flow rate reduced to $0.00067 \mathrm{~m}^{3} / \mathrm{s}$. In this case, the results were distributed as follows: $72 \%$ efficiency achieved after the first layer, $74 \%$ - the second, $75 \%$ - the third, $75 \%$ - the fourth, $79 \%$ - after the fifth.

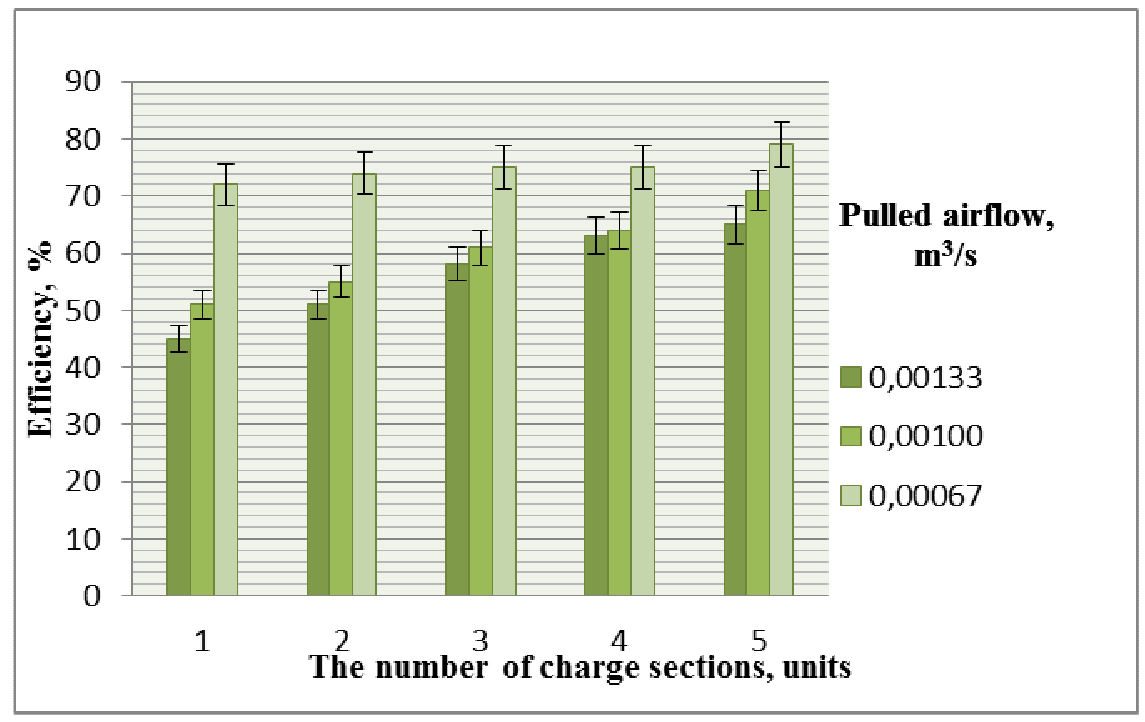

Fig. 2. Biofilter air cleaning efficiency depending on the number of layers of the load when the initial concentration of acetone vapor is $830.27 \mathrm{mg} / \mathrm{m}^{3}$

As we notice in the 2nd picture, the acetone concentration is decreased dramatically after the first biofilter cartridges filled with polymer woven material load. Biofilter efficiency significantly increased at lower flow of supplied air $\left(0.00067 \mathrm{~m}^{3} / \mathrm{s}\right)$ and after the first layer load acetone vapor concentrations is decreased from $830.27 \mathrm{mg} / \mathrm{m}^{3}$ to $232.67 \mathrm{mg} / \mathrm{m}^{3}$.

The following pollutant concentration measurements at each biofilter section was carried out by reducing the initial concentration from $830.27 \mathrm{mg} / \mathrm{m}^{3}$ to $640.49 \mathrm{mg} / \mathrm{m}^{3}$. Biofilter efficiency at different air flow ranges from $58 \%$ to $82 \%$ (see Fig. 3.). The following pollutant concentration measurements at each biofilter section was carried out by reducing the initial concentration from $640.49 \mathrm{mg} / \mathrm{m}^{3}$ to $426.99 \mathrm{mg} / \mathrm{m}^{3}$. When air flow is $0.00133 \mathrm{~m}^{3} / \mathrm{s}$ biofilter performance after the first load layer was $55 \%$, after the second layer $-57 \%$, after the third layer $-59 \%$, after the fourth $-62 \%$, and the fifth has risen to $65 \%$. The air flow is reduced to $0,00100 \mathrm{~m}^{3} / \mathrm{s}$ noticed that the efficiency of the first layer of the boot was $70 \%$, the second $72 \%$, after the third layer $-74 \%$, after the fourth $-76 \%$, while the fifth has risen to $80 \%$.

Measurements were repeated with flow reduced to $0.00067 \mathrm{~m}^{3} / \mathrm{s}$. In this case, the results were distributed as follows: $80 \%$ efficiency achieved after the first boot layer, $82 \%$ - the second, $83 \%$ - after the third, $84 \%$ - after the fourth, $85 \%-$ after the fifth.

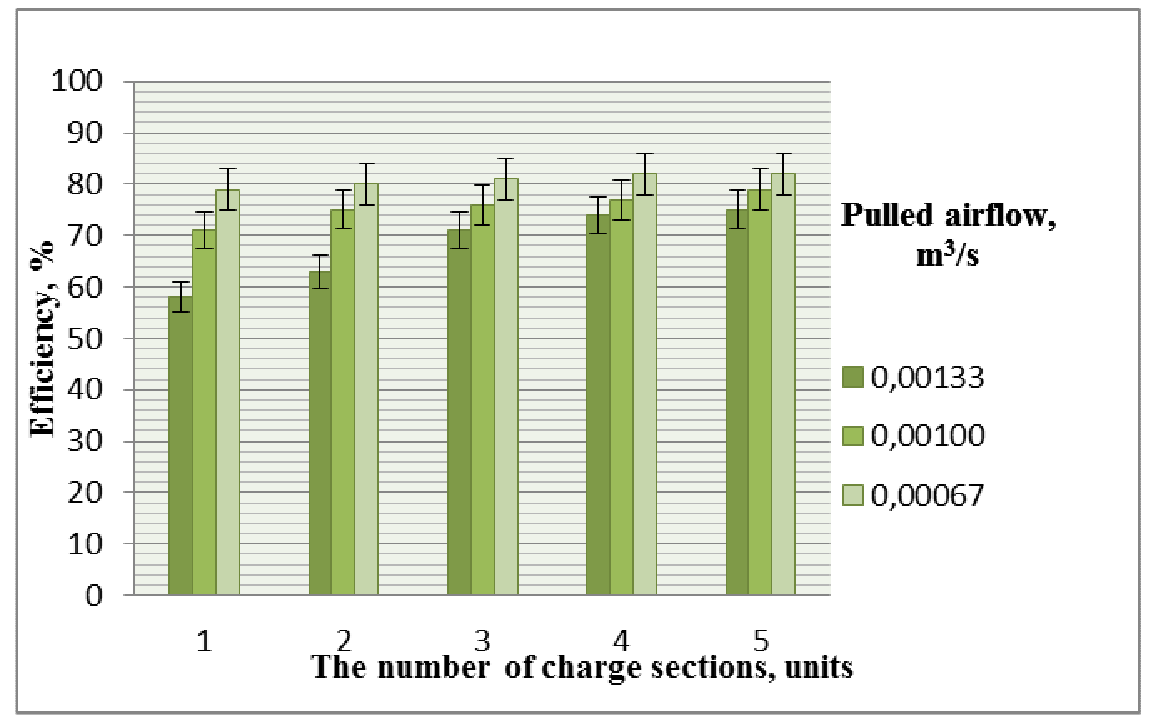

Fig. 3. Biofilter air cleaning efficiency depending on the number of layers of the load when the initial concentration of acetone vapor is $640.49 \mathrm{mg} / \mathrm{m}^{3}$ 
As we note from the 3rd picture, the acetone concentration decreased dramatically after the first biofilter cartridges. Biofilter efficiency significantly increased at lower supplied air flow to the devise $\left(0.00067 \mathrm{~m}^{3} / \mathrm{s}\right)$, and after the first load layer of acetone vapor concentrations decreased from $640.49 \mathrm{mg} / \mathrm{m}^{3}$ to $128.10 \mathrm{mg} / \mathrm{m}^{3}$.

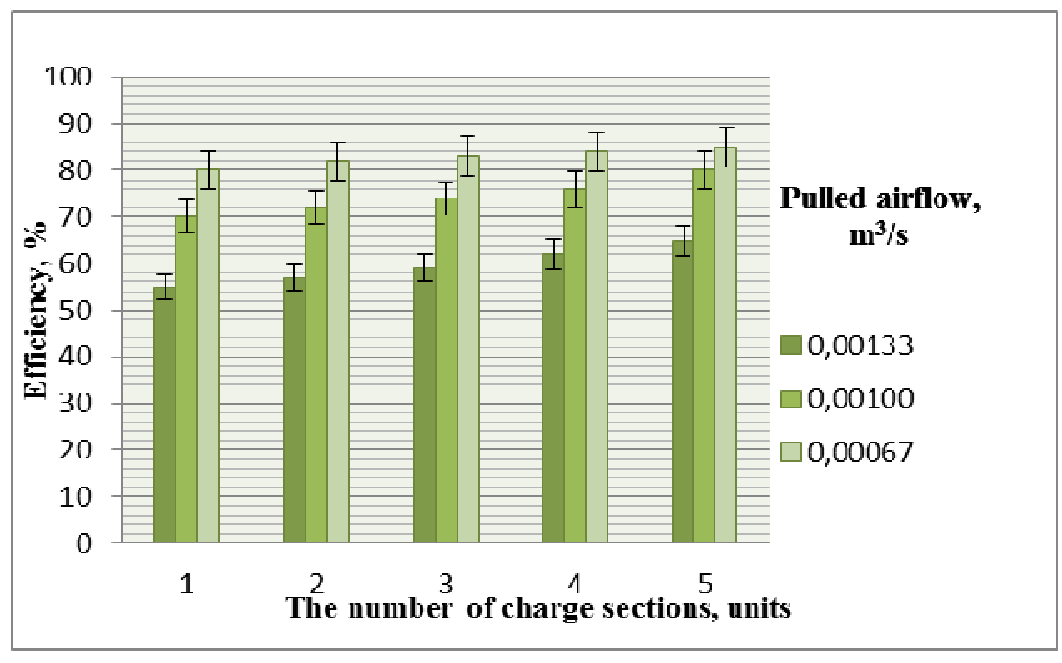

Fig. 4. Biofilter air cleaning efficiency depending on the number of layers of the load when the initial concentration of acetone vapor is $426.99 \mathrm{mg} / \mathrm{m}^{3}$

Acetone levels decreased dramatically after the first biofilter cassette (Fig. 4.). As we observe a significant increase in efficiency of the biofilter at a lower air flow supplied $\left(0.00067 \mathrm{~m}^{3} / \mathrm{s}\right)$ to the device, and after the first load layer of acetone vapor concentrations decreased from $426.99 \mathrm{mg} / \mathrm{m}^{3}$ to $85.40 \mathrm{mg} / \mathrm{m}^{3}$.

So, as already mentioned, the biofilter load filled with polymer woven material efficiency increased significantly with a lower air flow supplied to the device $\left(0.00067 \mathrm{~m}^{3} / \mathrm{s}\right)$ and experimental research has shown that at high substrate - acetone concentration enzyme active center is being occupied by the substrate. Under these conditions, a further increase in the concentration of the substrate is no longer effecting enzymatic reaction rate, because of all the active centers of the enzyme is already occupied. Therefore, by reducing the concentration of the pollutant the efficiency of the devise is increasing. The experiment showed a biofilter filled with polymeric material woven load air cleaning efficiency, which was $85 \% \pm 4.25 \%$. This means that, for example, if the initial acetone concentration was $426.99 \mathrm{mg} / \mathrm{m}^{3}$, after biofilter the acetone concentration was $64.05 \mathrm{mg} / \mathrm{m}^{3} \pm 3.20 \mathrm{mg} / \mathrm{m}^{3}$.

Research on air biocleaning from butanol. At the initial butanol concentration $1061.05 \mathrm{mg} / \mathrm{m}^{3} \mathrm{I}$ have found that biofilter efficiency at different flow ranges from $41 \%$ to $73 \%$ (Fig. 5.). Further air cleaning efficiency at every layer increases gradually. At pulled airflow $0.00133 \mathrm{~m}^{3} / \mathrm{s}$, the biofilter performance after the first charge layer was $41 \%$, after the second layer $-48 \%$, after the third layer $-59 \%$, after the fourth $-64 \%$, while the fifth has risen to $65 \%$. The air flow is reduced to $0.00100 \mathrm{~m}^{3} / \mathrm{s}$ noticed that the efficiency of the first layer of the boot was $58 \%$, after the second layer $-60 \%$, after the third layer $-65 \%$, after the fourth $-70 \%$, while the fifth has risen to $71 \%$. Measurements have been repeated with flow reduced to $0.00067 \mathrm{~m}^{3} / \mathrm{s}$. In this case, the results were distributed as follows: $60 \%$ efficiency achieved after the first boot layer, $64 \%$ - after the second, $65 \%$ - after the third, $71 \%$ - after the fourth, $73 \%$ - after the fifth.

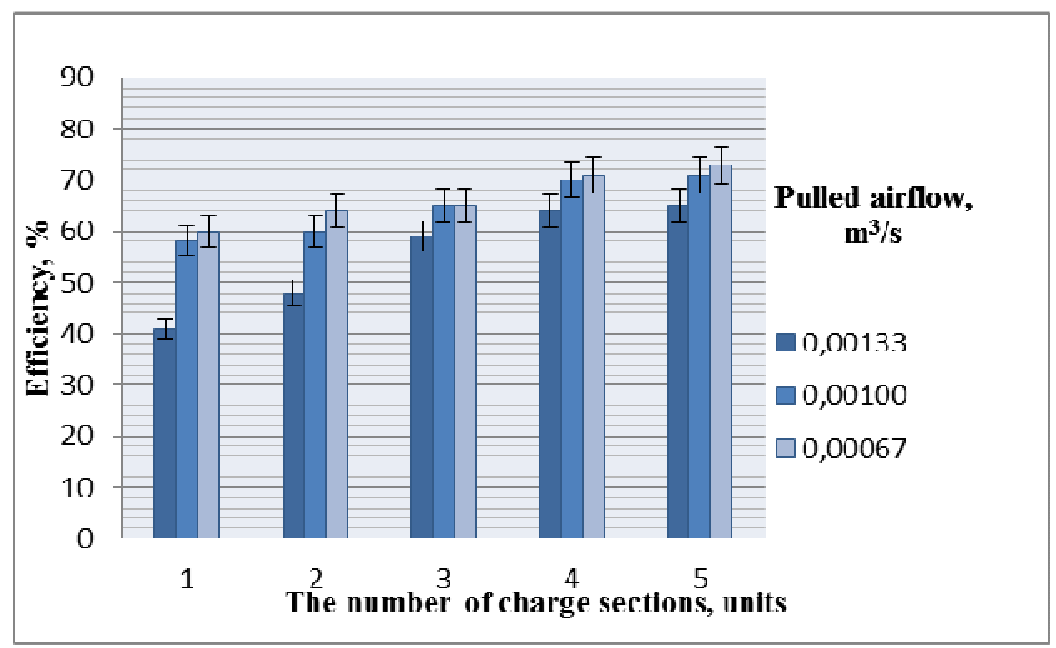

Fig. 5. Biofilter air cleaning efficiency depending on the number of layers of the load when the initial concentration of butanol vapor is $1061.05 \mathrm{mg} / \mathrm{m}^{3}$ 
As we notice in the 5th picture butanol (like acetone) levels weredecreased dramatically after the first biofilter cartridge. Biofilter efficiency significantly increased at lower air flow supplied to the device $\left(0.00067 \mathrm{~m}^{3} / \mathrm{s}\right)$, and after the first load layer of butanol vapor concentrations decreased from $1061.05 \mathrm{mg} / \mathrm{m}^{3}$ to $424.42 \mathrm{mg} / \mathrm{m}^{3}$.

The following pollutant concentration measurements at each biofilter section were carried out by reducing the initial concentration from $1061.05 \mathrm{mg} / \mathrm{m}^{3}$ to $818.52 \mathrm{mg} / \mathrm{m}^{3}$. Biofilter efficiency at different air content varied from $55 \%$ to $82 \%$ (Fig. 6.). Next we reduce the initial concentration from $818.52 \mathrm{mg} / \mathrm{m}^{3}$ to $545.12 \mathrm{mg} / \mathrm{m}^{3}$. Biofilter efficiency at different air flow ranged from $69 \%$ to $84 \%$ (Fig. 7 ).

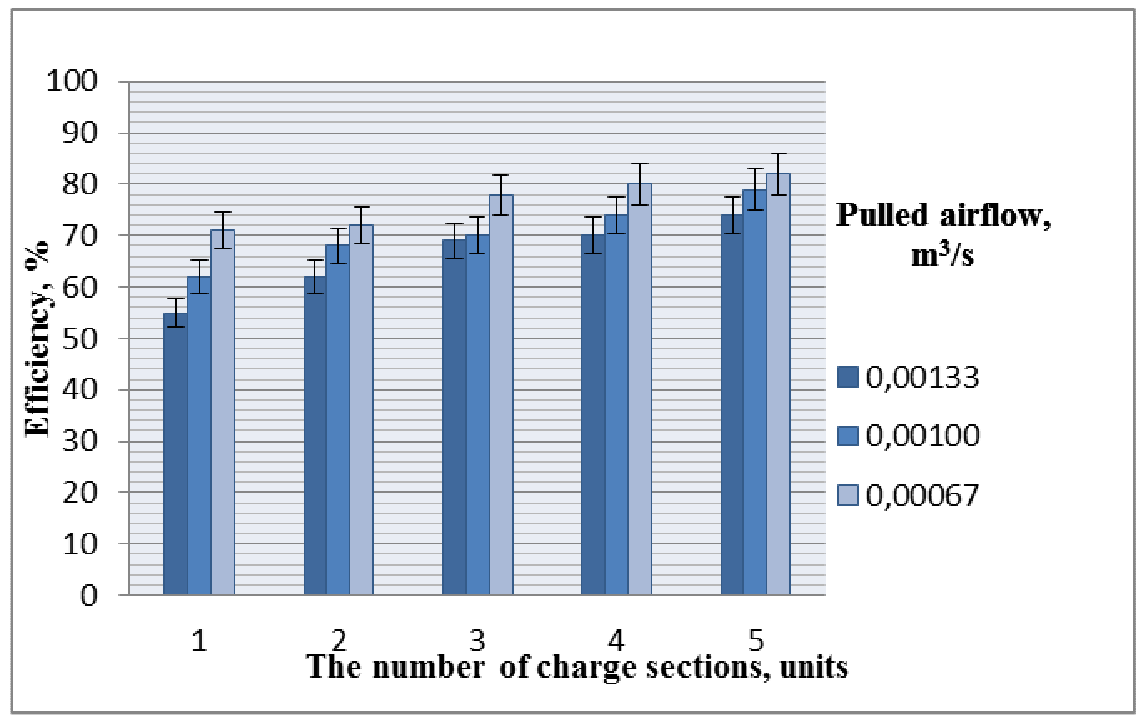

Fig. 6. Biofilter air cleaning efficiency depending on the number of layers of the load when the initial concentration of butanol vapor is $818.52 \mathrm{mg} / \mathrm{m}^{3}$

Butanol concentration dropped sharply after the first biofilter cassette (Fig. 6.). As we observe a significant increase in efficiency of the biofilter at a lower air flow supplied to the device $\left(0.00067 \mathrm{~m}^{3} / \mathrm{s}\right)$, and after the first boot layer of butanol vapor concentrations decreased from $818.52 \mathrm{mg} / \mathrm{m}^{3}$ to $237.37 \mathrm{mg} / \mathrm{m}^{3}$.

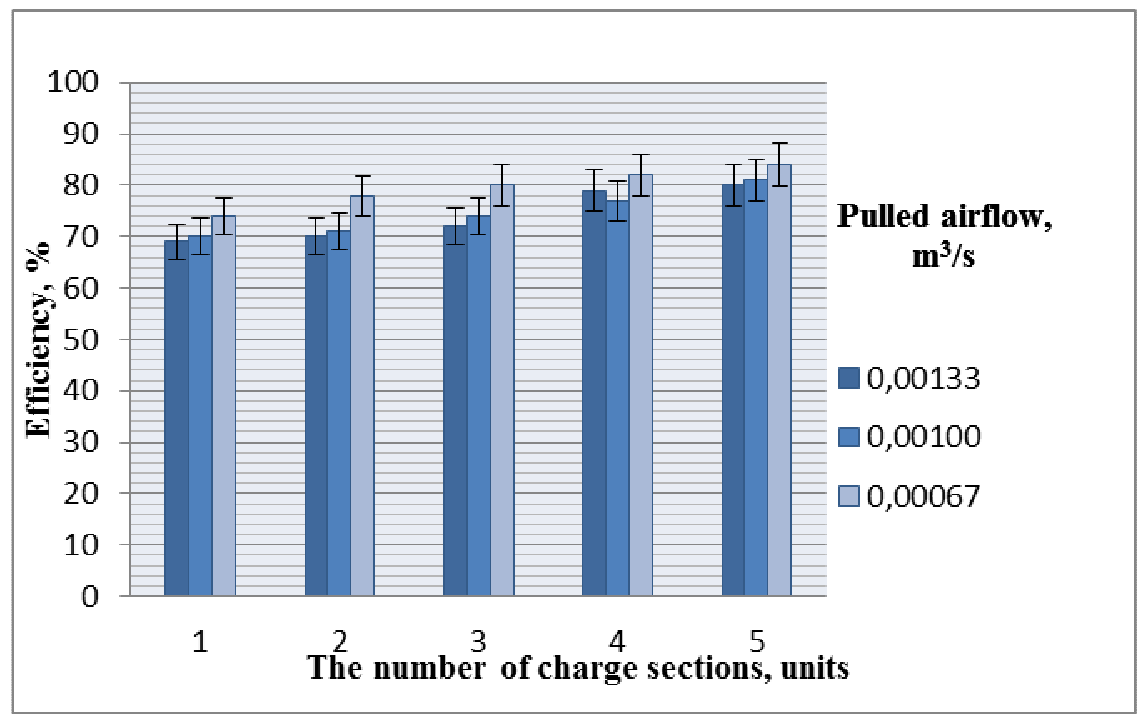

Fig. 7. Biofilter air cleaning efficiency depending on the number of layers of the load when the initial concentration of butanol vapour is $545.12 \mathrm{mg} / \mathrm{m}^{3}$

Butanol concentration dropped sharply after the first biofilter cassette (Fig. 7). Biofilter efficiency significantly increased at lower air flow supplied to the device $\left(0.00067 \mathrm{~m}^{3} / \mathrm{s}\right)$, and after the first load layer of butanol vapor concentrations decreased from $545.12 \mathrm{mg} / \mathrm{m}^{3}$ to $141.73 \mathrm{mg} / \mathrm{m}^{3}$.

So, as already mentioned, the efficiency of the biofilter greatly increased at lower air flow supplied to the device $\left(0.00067 \mathrm{~m}^{3} / \mathrm{s}\right)$ and experimental research has shown that reducing the concentration of the substrate increases the efficiency of the devise. The experiment showed a biofilter filled with polymeric material woven air cleaning efficiency, which was $84 \% \pm 4.2 \%$. Biofilter cleaning butanol concentration decreases from $545.12 \mathrm{mg} / \mathrm{m}^{3}$ to $87.22 \mathrm{mg} / \mathrm{m}^{3} \pm 4.36 \mathrm{mg} / \mathrm{m}^{3}$. 
The biofilter efficiency for cleaning air from butanol has been achieved: $84 \% \pm 4.2 \%$ and $85 \% \pm 8.5 \%$ - for cleaning acetone contaminated air (Fig. 8).

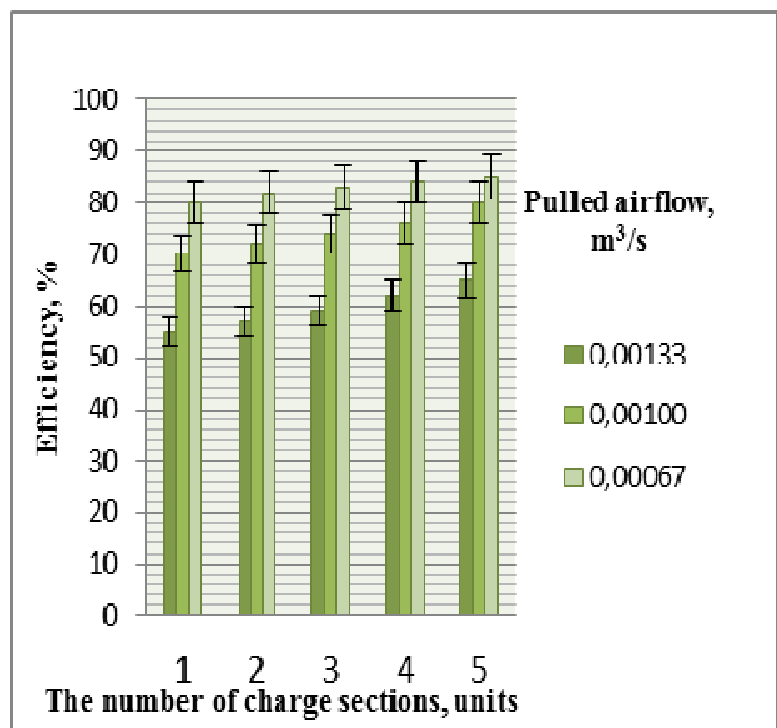

(a)

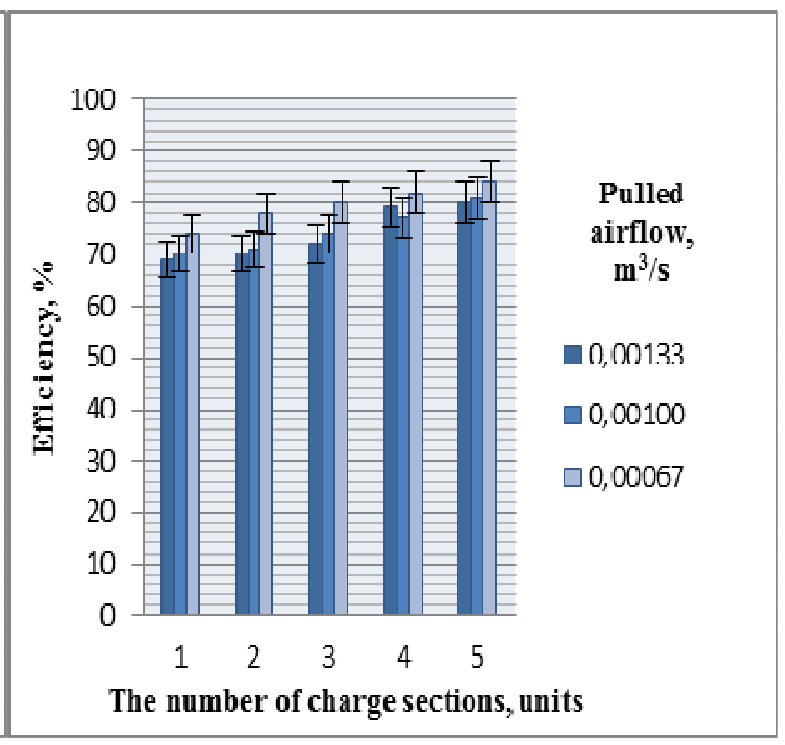

(b)

Fig. 8. Biofilter air cleaning efficiency depending on the number of layers of the load a - when initial acetone concentration $-426.99 \mathrm{mg} / \mathrm{m}^{3}$;

$\mathrm{b}$ - when the initial concentration of butanol vapors is $545.12 \mathrm{mg} / \mathrm{m}^{3}$

From these graphs, you can easily notice that the butanol concentration of pollutants changed very slowly, and acetone sharply from $55 \%$ to $84 \%$. Steeper acetone concentrations change may be due to changes in the biofilter and the acetone tendency for quicker evaporation.

The experiment showed the dependence between the biofilter treatment efficiency and the supply of substrate (acetone or butanol). Based on test results, the maximum air cleaning efficiency of the biofilter achieved $85 \%$. This cleaning efficiency has been achieved by allowing through the device the acetone vapor contaminated air at the volume of $2.41 \mathrm{~m}^{3} / \mathrm{hr}$. Thus, acetone has been effectively divided by the microorganisms. This volatile organic compound is completely soluble in water, therefore it is well absorbed by the biofilm arising on the load surface.

Allowing air contaminated with volatile organic compounds through synthetic loadings, such as polyurethane fiber, increasing the initial concentration of pollutants extremely high air cleaning efficiency can be reached - from $64.3 \%$ to $98.8 \%$ when the pollutant concentration of $16 \mathrm{~g} /\left(\mathrm{m}^{3} \cdot \mathrm{h}\right)$ and from $77.4 \%$ to $99.1 \%$ when the gas concentration from 35 to $140 \mathrm{~g} /\left(\mathrm{m}^{3} \cdot \mathrm{h}\right)$ (Yang et al, 2011). The use of polyurethane foam efficiency can reach and exceed 90\% (Qi and Moe 2006).

So, let's compare the data obtained in the experimental studies with the Lithuanian and foreign authors results. According to our test results, the maximum air cleaning efficiency of the biofilter in the treatment of contaminated air from acetone was $85 \% \pm 4.25 \%$, and cleaning from butanol $-84 \% \pm 4.2 \%$. Lithuanian scientists reached $90 \% \pm 8 \%$ efficiency by cleaning butanol contaminated air using a biofilter loaded with pine bark. One of the Lithuanian scientists, namely doc. Dr. Alvydas Zagorskis while exploring biofilter with irrigation camera laoded with zeolite, wood chips and bark, reached a high level of cleaning from acetone. Biofilter efficiency was $98 \% \pm 1 \%$. Spanish scientists used biofilter loaded with ceramic balls and reached air contaminated with xylene and butanol vapors cleaning efficiency of 75\%. Also, researchers from Louisiana State with a biofilter loaded with activated carbon, cleaned the air contaminated with acetone and toluene with $98 \% \pm 1 \%$ efficiency. Comparing our data with other scientists' results, we can conclude that the biofilter with synthetic origin polymer load efficiency is in many cases less, but the load effectiveness is adequate to clean the air of volatile organic compounds.

\section{Findings}

1. Based on the test results, the maximum air cleaning efficiency of the biofilter was $85 \%$. This cleaning efficiency achieved through the biofilter loaded with synthetic origin polymer charge, allowing the acetone vapors contaminated air at a rate of $2.41 \mathrm{~m}^{3} / \mathrm{hr}$.

2. It was found that the air biofilter devise efficiency improves by reducing air flow rate $(801 / \mathrm{min}$ to $401 / \mathrm{min}$ or $0.00133 \mathrm{~m}^{3} / \mathrm{s}$ of up to $0.00067 \mathrm{~m}^{3} / \mathrm{s}$ ), as well as increasing the height of the load and the number of layers ( 1 to 5 pcs.).

3. The experimental study showed that at high substrate (acetone or butanol) concentration the enzyme active center is being occupied by the substrate. Under these conditions, a further increase in the concentration of the substrate is no longer 
effecting active enzymatic reaction rate, because all the active centers of the enzyme are already occupied. Therefore, reducing the concentration of the pollutant treatment increases the efficiency.

4. Research has shown that the efficiency of the filter, by cleaning the air of VOCs, depends on the allowable pollutant concentrations and from the pollutant properties. When cleaning the air from acetone the efficiency of $85 \% \pm 4.25 \%$ has been reached, cleaning the air from butanol the efficiency was $84 \% \pm 4.2 \%$. Steeper acetone concentration change in the biofilter may be due to acetone tendency for quicker evaporation. This volatile organic compound is completely soluble in water, therefore it is well absorbed by the biofilm arising on the load surface.

\section{References}

[1] Andres, Y.; Dumont, E.; Gerente, C. 2009. Characterization techniques of packing material colonization in gas biofiltration processes, Canadian Journal of Civil Engineering 36(12): 1895-1902. http://dx.doi.org/10.1139/L09-143

[2] Ardjmand, M.; Safekordi, A.;Farjadfard, S. 2005. Simulation of biofi lter used for removal air contaminants (ethanol), International Journal of Environmental Science and Technology 2(1): 69-82. http://dx.doi.org/10.1007/BF03325860

[3] Khan, F. I.; Ghoshal, A. K. 2000. Removal of volatile organic compounds from polluted air, Journal of Loss Prevention in the Process Industries 13(6): 527-545. http://dx.doi.org/10.1016/S0950-4230(00)00007-3

[4] Miao, J.; Zheng, L.; Guo, X. 2005. Restaurant emissions removal by a biofi lter with immobilized bacteria, Journal of Zhejiang University Science 6B(5): 433-437. http://dx.doi.org/10.1631/jzus.2005.B0433

[5] Saravanan, V.; Rajamohan, N. 2009. Treatment of xylene polluted air using press mud-based biofilter, Journal of Hazardous Materials 162: 981-988. http://dx.doi.org/10.1016/j.jhazmat.2008.05.158

[6] Yang, Ch.; Yu, G.; Zeng, G.; Yang, H.; Chen, F.; Jin, C. 2011. Performance of biotrickling filters packed with structured or cubic polyurethane sponges for VOC removal, Journal of Environmental Sciences 23(8): 1325-1333. http://dx.doi.org/10.1016/S1001-0742(10)60565-7

[7] Baltrènas, P.; Zagorskis, A. 2010b. Air treatment efficiency of biofilter with adsorbing zeolite layer, Ecology 56(1-2): 72-78.

[8] Baltrenas, P.; Zigmontienè, A.; Vaiškūnaitè, R. 2004. Air purification biotechnology, Monograph. Vilnius: Technology, 205 p.

[9] Cai, Z.; Kim D.; Sorial, G. A. 2006. Performance of Trickle-Bed Air Biofilter: A Comparative Study of a Hydrophilic and a Hydrophobic VOC, Water, Air, and Soil Pollution: Focus 6(1-2): 57-69. http://dx.doi.org/10.1007/s11267-005-9013-2

[10] Deshusses, M. A. 1997. Biological waste air treatment in biofi lters, Environmental Biotechnology 8: 335-339.

[11] Duan, H.; Koea, L. C. C.; Yan, B.; Chenb, X. 2006. Biological treatment of H2S using pellet activated carbon as a carrier of microorganisms in a biofilter, Water Res. 40: 2629-2636. http://dx.doi.org/10.1016/j.watres.2006.05.021

[12] Eldon, R.; Murthy, D. V. S.; Swaminathan, T. 2010. Effect of flow rate, concentration and transient-state operations on the performance of a biofilter treating xylene vapors, Water, Air, Soil Pollution 211(1-4): 79-93.

[13] Komilis, D. P.; Ham, R. K.; Park, J. K. 2004. Emission of volatile organic compounds during composting of municipal solid wastes, Wat Res 38: 7071714. http://dx.doi.org/10.1016/j.watres.2003.12.039

[14] McNevin, D.; Barford, J. 2000. Biofiltration as an odour abatement strategy, Biochemical Enginiering. J. 5: 231-242. http://dx.doi.org/10.1016/S1369-703X(00)00064-4

[15] Neves, L. C.; Miyamura, T. T.; Moraes, D. A.; Penna, T. C.; Converti, A. 2006. Biofiltration methods for the removal of phenolic residues, Applied Biochemistry and Biotechnology 129(1): 130-52. http://dx.doi.org/10.1385/ABAB:129:1:130

[16] Nicolai, R. E.; Lefers, R. M. 2006. Biofilters used to reduce emissions from livestock housing - A literature review. Available from: South Dakota State University, Brookings, South Dakota.

[17] Pineda, R.; Alba, J.; Thalasso, F.; Ponce-Noyola, T. Microbial characterization of organic carrier colonization during a model biofiltration experiment, Letters in Applied Microbiology 38: 522 . http://dx.doi.org/10.1111/j.1472-765X.2004.01530.x

[18] Zarook, S. M.; Shaikh, A. A.; Ansar, Z; Baltizis, B. C. 1997. Biofiltration of volatile organic compound (VOC) mixtures under transient conditions, Chem. Eng. Sci. 52: 4135-4142. http://dx.doi.org/10.1016/S0009-2509(97)00256-X

[19] Qi, B.; Moe, W. M. 2006. Performance of low pH biofilters treating a paint solvent mixture: Continuous and intermittent loading, $J$ Hazard Mater 135(1-3): 303-310. http://dx.doi.org/10.1016/j.jhazmat.2005.11.065

[20] Zagorskis, A.; Spiečiūtè, R. Drip-biofilter aerodynamic resistance studies, in Environmental Engineering of the 10th Lithuanian Conference of Young Scientists conference "Science - Future of Lithuania", held posts in the material 3(5): 64-69 